\title{
Arsenic trioxide inhibits EBV reactivation and promotes cell death in EBV-positive lymphoma cells
}

\author{
Qinyan Yin ${ }^{1}$, Mark Sides ${ }^{1,4}$, Christopher H. Parsons ${ }^{2}$, Erik K. Flemington ${ }^{3}$ and Joseph A. Lasky ${ }^{1 *}$
}

\begin{abstract}
Background: Epstein-Barr Virus (EBV) is associated with hematopoietic malignancies, such as Burkitt's lymphoma, post-transplantation lymphoproliferative disorder, and diffuse large B-cell lymphoma. The current approach for EBVassociated lymphoma involves chemotherapy to eradicate cancer cells, however, normal cells may be injured and organ dysfunction may occur with currently employed regimens. This research is focused on employing arsenic trioxide (ATO) as EBV-specific cancer therapy takes advantage of the fact the EBV resides within the malignant cells.
\end{abstract}

Methods and results: Our research reveals that low ATO inhibits EBV gene expression and genome replication. EBV spontaneous reactivation starts as early as $6 \mathrm{~h}$ after re-suspending EBV-positive Mutu cells in RPMl media in the absence of ATO, however this does not occur in Mutu cells cultured with ATO. ATO's inhibition of EBV spontaneous reactivation is dose dependent. The expression of the EBV immediate early gene Zta and early gene BMRF1 is blocked with low concentrations of ATO $(0.5 \mathrm{nM}-2 \mathrm{nM})$ in EBV latency type I cells and EBV-infected PBMC cells. The combination of ATO and ganciclovir further diminishes EBV gene expression. ATO-mediated reduction of EBV gene expression can be rescued by co-treatment with the proteasome inhibitor MG132, indicating that ATO promotes ubiquitin conjugation and proteasomal degradation of EBV genes. Co-immunoprecipitation assays with antibodies against Zta pulls down more ubiquitin in ATO treated cell lysates. Furthermore, MG132 reverses the inhibitory effect of ATO on anti-lgM-, PMA- and TGF- $\beta$-mediated EBV reactivation. Thus, mechanistically ATO's inhibition of EBV gene expression occurs via the ubiquitin pathway. Moreover, ATO treatment results in increased cell death in EBV-positive cells compared to EBV-negative cells, as demonstrated by both MTT and trypan blue assays. ATO-induced cell death in EBV-positive cells is dose dependent. ATO and ganciclovir in combination further enhances cell death specifically in EBV-positive cells.

Conclusion: ATO-mediated inhibition of EBV lytic gene expression results in cell death selectively in EBV-positive lymphocytes, suggesting that ATO may potentially serve as a drug to treat EBV-related lymphomas in the clinical setting.

Keywords: Epstein-Barr virus, EBV, Arsenic trioxide, ATO, Lymphoma, Cancer, Cancer therapy

\section{Background}

Epstein-Barr virus (EBV) is a ubiquitous DNA virus that is implicated in the pathogenesis of hematopoietic malignancies including Burkitt's lymphoma, Hodgkin lymphoma, post-transplant lymphoma, AIDS-associated lymphomas, age-associated B-cell lymphoma, primary central nervous system lymphomas, NK/T-cell lymphoma and

\footnotetext{
* Correspondence: jlasky@tulane.edu

1 Department of Medicine, Section of Pulmonary Disease, Tulane University

School of Medicine, 1430 Tulane Ave, New Orleans, LA 70112, USA

Full list of author information is available at the end of the article
}

diffuse large B-cells lymphoma, along with nonhematopoietic tumors. EBV can establish a latent stage marked by expression of EBV latent genes (e.g. EBNA1, EBNA2, EBNA-LP, EBNA3A/3B/3C, LMP1, LMP2A/2B), and a lytic stage that expresses a set of EBV lytic genes and production of infectious virions. The switch from latent to lytic stage is driven by EBV immediate-early genes, such as BZLF1 (Zta) in vivo or by various commercial reagents in vitro, for example phorbol 12-myristate 13-acetate [1, 2], anti-IgG and anti-IgM [3-6], $\mathrm{Ca}^{2+}$ ionophore [7], bone morphogenetic proteins (BMPs) [8], and transforming 
growth factor beta 1 (TGF- $\beta 1$ ) [9-11]. Recently, we discovered that arsenic trioxide (ATO) activates the EBV lytic cycle in nasopharyngeal carcinoma cells [12]. In general, the EBV latent cycle is associated with tumorigenesis because latent genes such as LMP1 are oncogenic, whereas the EBV lytic cycle is often considered detrimental to cell survival. However, there is evidence that the EBV lytic cycle may play a role in supporting lymphoid malignancies [13-15], in as much as patients with a higher titer of EBV lytic antigens in plasma have higher tumor recurrence rates after therapy and a poorer prognosis [16-20]. Whereas patients with lower plasma EBV DNA levels respond more favorably to current treatment regimens [21].

The mechanism by which EBV lytic genes induce malignancies has been studied but still requires clarification. The accumulated reports indicate that EBV lytic genes are directly responsible for causing malignancies and cell growth via regulation of cellular signals. Zta degrades the tumor suppressor p53 and inhibits its transcriptional function [22-26]; EBV lytic genes also inhibit antiviral cytokines such as TNF-alpha, and stimulate synthesis of cellular cytokines, such as interleukin-10, -8 , and -13 , which serve as growth factors to promote cell cycling and thereby tumor cell proliferation [27-29]. Moreover, induction of matrix metalloproteinases by Zta could potentially enhance metastasis of EBV-positive tumors cells via matrix degradation [30, 31]. Taken together, EBV alters cellular processes via genetic and epigenetic mechanisms, and consequently EBV-positive cell growth is dependent upon retention of the EBV genome [32-34]. Consequently, forced loss of the EBV genome in EBV-positive cells disrupts this balance and induces cell death. Studies using EBV-positive lymphoma cells have demonstrated that loss of the EBV genome in Akata cells results in cell death [35-37]. These manuscripts imply that inhibition of EBV lytic reactivation may reduce the occurrence of cancer and suggest that antiviral therapy may be useful for treating EBV-related malignancies [38].

EBV genome replication is driven by oriP during the latent phase, and by oriLyt during the lytic phase. OriLyt is located within divergent promoter regions of BHLF1 and BHRF1 and consists of two essential core elements, namely the BHLF1 promoter containing Zta response elements (ZREs) and the TD element for Sp1 binding [39]. EBV lytic DNA replication is facilitated by six core early lytic viral replication factors including: the DNA polymerase processivity factor (BMRF1 or EA-D), the primase BSLF2, the helicase BBLF4, the helicase-primase complex BBLF2/3, the single-stranded DNA-binding protein BALF2 and the DNA polymerase BALF5 [40-43]. Importantly, BZLF1 is a central regulator for lytic replication, binding directly to ZRE sites on the upstream domain of oriLyt and interacting with other viral core replication proteins, such as BMRF1, BALF2 and BBLF4 [44-46].
ATO is a highly effective in treating acute promyelocytic leukemia [47] via degradation of promyelocytic leukemia (PML) nuclear bodies through a ubiquitin-mediated pathway [48-51]. ATO treatment results in degradation of all 7 major PML isoforms, in which PMLV is the most highly degraded isoform and PMLIV is the least degraded isoform [52]. ATO binds to PML-RAR $\alpha$ protein directly and induces its SUMO modification by recruiting a ringdomain-containing ubiquitin E3 ligase (RNF4), along with ubiquitin and the proteasome, to PML nuclear bodies, resulting in the degradation of PML-RAR $\alpha[53,54]$. EBV latent proteins (LMP2A, LMP1 and EBNA1) interact with the cellular proteasome/ubiquitin pathway to control the EBV latency. However, EBV lytic proteins, such as Zta, Rta and BMRF1, can also be regulated by sumoylation and ubiquitination. Zta is a bZIP protein that can be SUMO1 modified on Lys 12 and Lys15 [55, 56]. Rta can be sumoylated on Lys-19, Lys-213, and Lys-517 [57]. SUMOtargeted RNF4 interacts with Rta and enhances Rta and BMRF1 ubiquitination [58]. Overexpression of Zta in EBV latently infected cells results in dispersion of PML nuclear bodies and induces loss of SUMO1-modified isoforms of PML protein [59, 60]. Knockdown of PML reduces the production of viral particles and EBV genome in EBVpositive P3HR1 cells, supporting the concept that PML nuclear bodies play a role in EBV capsid assembly and viral lytic DNA replication [61].

We previously demonstrated that ATO activates the EBV lytic cycle in EBV-positive epithelial cells and inhibits tumor growth in a xenograft model [12]. In contrast, in this manuscript we did not find that arsenic induced EBV reactivation in Burkitt's lymphoma cells. In the work presented here we show that arsenic inhibits the expression of EBV lytic genes Zta, Rta and BMRF1, and promotes cell death in EBV-positive lymphoma cells. Herein, we also report that ATO regulates EBV reactivation via ubiquitin/ proteasome-dependent proteolysis. Current therapies for anti-EBV-positive lymphomas are not vastly different in comparison to EBV-negative lymphomas. We submit that arsenic may be a potential antiviral chemotherapy for treatment of EBV-associated lymphomas.

\section{Methods}

\section{Cell culture and treatment}

EBV-positive latency type I Burkitt's lymphoma cell lines (Mutu, Akata, BX-1, Rael and SAV5), an EBV latency type II B lymphocyte cell line (Cl13), and EBV latency type III lymphoblastoid cells (JY), have been maintained in our laboratory for more than 20 years through freezethaw cycles. The Farage EBV-positive diffuse large B-cell lymphoma cell line was purchased from ATCC. PBMC cells were a gift from Dr. Frédéric Ganapamo. Cell culture conditions were as described previously [62]. Briefly, all cell lines were cultured in RPMI 1640 media 
supplemented with $10 \%$ heat-inactivated fetal bovine serum (Gibco) in a humidified incubator with $5 \% \mathrm{CO}_{2}$ at $37{ }^{\circ} \mathrm{C}$. The cells were split 1:1 1 day before treatment. On the day of treatment, cells were enumerated and viability assessed using trypan blue exclusion staining. Cells were re-suspended with fresh media at the confluence of 1 $\times 10^{6}$ cells per ml, and ATO was added at the indicated concentrations. For proteinase or sumoylation inhibitor experiments, MG132 or Ginkgolic Acid respectively were added $4 \mathrm{~h}$ or $16 \mathrm{~h}$ prior to harvest. ATO (Sigma \# A1010) was dissolved in $1 \mathrm{M} \mathrm{NaOH}$ and stored at $-20{ }^{\circ} \mathrm{C}$ as a $250 \mathrm{mM}$ stock solution. The $1 \mu \mathrm{M}$ working solution was prepared by dilution in sterile PBS (arsenic is adherent to commercial cell culture filters, so such filters were not employed). Ganciclovir was dissolved in $0.1 \mathrm{~N} \mathrm{HCl}$ at a concentration of $10 \mathrm{mg} / \mathrm{ml}$ and stored at $-20{ }^{\circ} \mathrm{C}$.

\section{Western blotting and immunoprecipitation}

Cells were lysed with RIPA buffer (Cell Signaling) supplemented with $0.1 \mathrm{M}$ phenylmethyl sulfonyl fluoride (PMSF), protease inhibitor mixture, and phosphatase inhibitors 2 \& 3 (Sigma)). Protein concentrations for western blotting and immunoprecipitation were determined using the Bio-Rad protein assay reagent and a Beckman Coulter spectrophotometer. Immunoprecipitation experiments were conducted as described previously [63]. Briefly, $500 \mu \mathrm{g}$ of protein was used for each immunoprecipitation and precleared with $50 \mu \mathrm{l}$ protein A/G sepharose beads (Santa Cruz) for $6 \mathrm{~h}$. Antibody $(2 \mu \mathrm{g})$ was incubated with $20 \mu \mathrm{l}$ protein A/G sepharose beads for $6 \mathrm{~h}$ to overnight. The immune-complexes were washed 3 times with RIPA buffer before being resolved using $2 \times$ SDS-PAGE loading buffer (sigma) and separated on a $4-20 \%$ Tris- $\mathrm{HCl}$ gradient SDSPAGE gel (BioRad). The signal was detected using the Odyssey Infrared Imaging System (Li-Cor Biosciences). The following antibodies were used: Actin (sc-1616), Zta (Argene 11-007), Rta (Argene 11-008), BMRF1 (EBV-01848,180), BGLF4 (Argent AP8057b), VCA (Argene 11-019), LMP1 (BD 559898) and GAPDH (Cell Signaling 2118 L).

\section{RNA extraction and quantitative reverse transcription (RT)-PCR}

Total cellular RNA was isolated using the RNeasy Plus mini kit (Qiagen \#74136) and was reverse transcribed using the iScript cDNA Synthesis Kit (BioRad, Cat\# 170-8890). The expression level of EBV genes, Zta and LMP1 were determined by SYBR green dye chemistry and calculated using the $2^{-\triangle \Lambda C T}$ method. Primers used for RT-PCR: LMP1 forward: 5'-CTACTGATGATCACCCTCCT$3^{\prime}$ and reverse: 5'-ATACCGAAGACAAGTAAGCA-3'; Zta forward: 5' GGGGGATAATGGAGTCAACA 3' and reverse: 5' GGAAACCACAACAGCCAGAA 3'; 36B4 forward: 5'CGAGGTGGAAGTCCAAGT-3' and reverse: 5'-ATGTGGT GCATCTGGTTG-3'.

\section{Cellular and viral DNA extraction and quantitative real-time PCR}

Total cellular DNA was isolated with DNAzol (Invitrogen \#10503-027) and was quantified using the nanodrop method. Four ng of DNA was used for real-time PCR in a $20 \mu \mathrm{l}$ volume. Viral DNA was isolated from media as described previously [63]. Briefly, cell culture media was filtrated through a $0.45 \mu \mathrm{m}$ SFCA filter and incubated with proteinase $\mathrm{K}$ (Invitrogen) at $37{ }^{\circ} \mathrm{C}$ for $1 \mathrm{~h}$ to overnight, followed by incubation at $95{ }^{\circ} \mathrm{C}$ for $15 \mathrm{~min}$ prior to extraction using phenol/chloroform. 100× diluted media extraction was used for real-time PCR with primers spanning the BamHI Z region and Q promoter $(\mathrm{Qp})$ regions of the EBV genome and housekeeping gene GAPDH. The quantitative level was calculated using the $2^{-\Delta \Delta C T}$ method. Primers used for PCR were: BamHI Z forward: 5'-TTGA CACCAGCTTATTTTAGACACTTCT-3 and reverse: 5'TTACCTGTCTAACATCTCCCCTTTAAA-3'; Qp forward: 5'-AAATTGGGTGACCACTGAGG-3' and reverse: 5'-C ATACACCGTGCGAAAAGAA-3'; GAPDH Forward: 5'-A AGGTGAAGGTCGGAGTCAAC-3' and reverse 5'-GGG GTCATTGATGGCAACAATA-3'.

\section{MTT assay and cell viability}

The MTT assay was performed following the manufacturer's instructions (Sigma \#M-8910). Briefly, cells were cultured in phenol free medium and an equal volume of reconstituted MTT was added onto the cells. The MTT solubilization solution was added and mitochondrial dehydrogenases activity was measured using a microplate auto reader (Bio-tek Instruments) after 2-4 h of incubation. Cell viability was measured by enumeration using a trypan blue (Invitrogen) method.

\section{Statistical analysis}

Statistical significance of each variable was assessed using one-way ANOVA.

\section{Results \\ ATO inhibits EBV lytic gene expression and genome replication ATO inhibits EBV lytic gene expression}

EBV-positive latency type I cell Mutu cells displayed spontaneous reactivation after being re-suspended in fresh media for $6 \mathrm{~h}$, and reached maximal lytic cycle by day 1 (Fig. 1a left). The EBV lytic gene BMRF1 and immediate early gene Zta were induced as early as $6 \mathrm{~h}$ after resuspension in fresh media. In contrast, BMRF1 was not induced when the media contained ATO, and the expression of Zta and Rta were lower compared with no treatment (NT) at day 1, 2 and 3 (Fig. 1a right). ATO-mediated EBV inhibition was dose-dependent (Fig. 1b). ATO inhibited expression of the EBV lytic genes BMRF1 and Zta in EBV latency type I cells, Mutu (Fig. 1b left) and Rael (Fig. 1b 


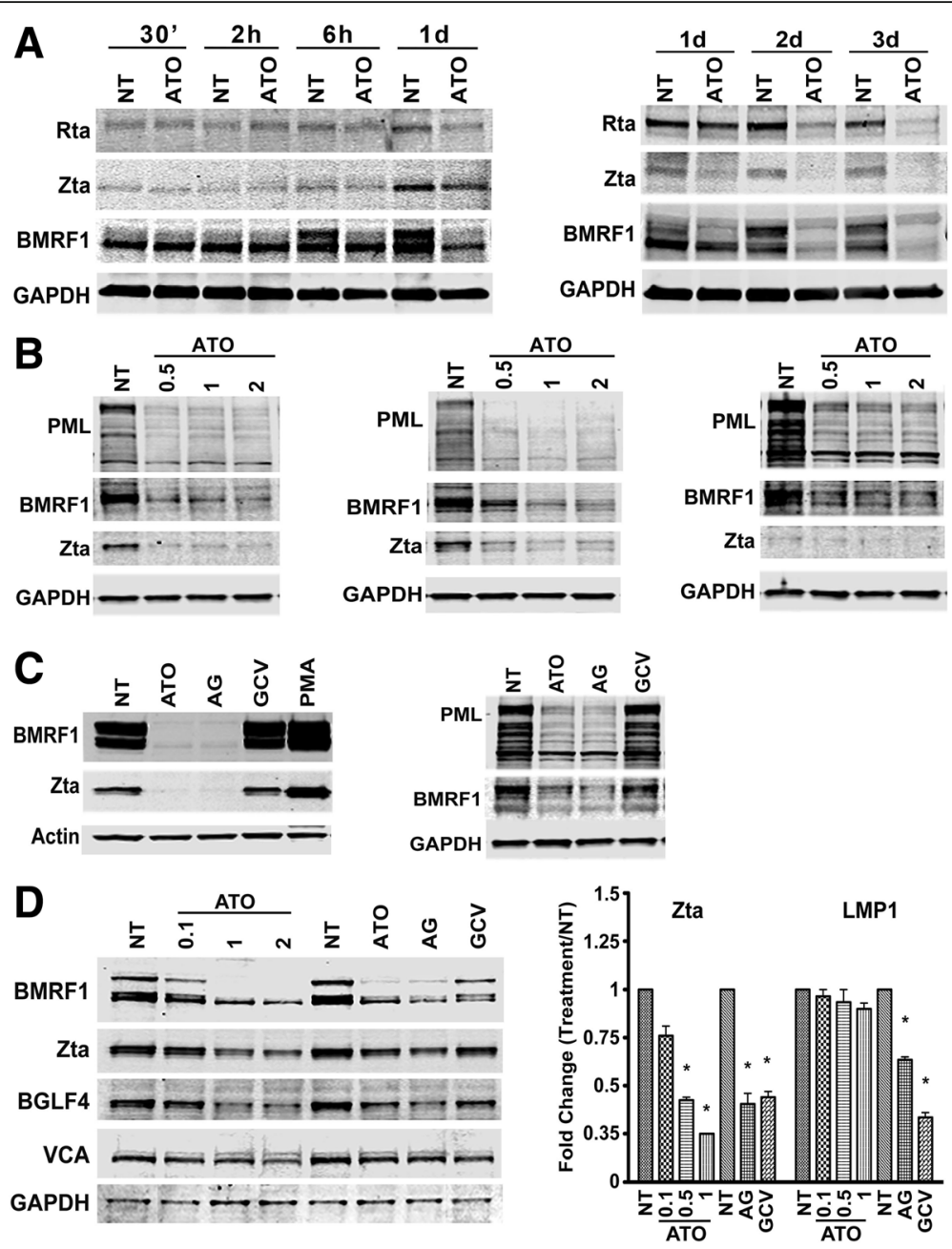

Fig. 1 ATO inhibited EBV reactivation at low concentrations in EBV-positive lymphoma cells. a ATO inhibited EBV spontaneous reactivation in Mutu cells. Western blotting detected EBV spontaneous reactivation within $6 \mathrm{~h}$ after re-suspending cells, but not in cells cultured in the presence of $1 \mathrm{nM}$ of ATO. b ATO inhibited EBV lytic gene expression in a dose-dependent manner. EBV latency type I cells (from left to right: Mutu, Rael and PBMC) were treated with various concentrations of ATO $(0.5 \mathrm{nM}-2 \mathrm{nM})$ for 3 days and harvested for western blotting. c Co-treatment with ATO and GCV (AG) inhibits EBV lytic gene expression. Western blotting assessment of EBV lytic gene expression in Rael (left) and SAV5 (right) after treatment with 1 nM ATO and/or $45 \mu \mathrm{M}$ GCV for 3 days. AG indicates treatment with ATO plus GCV. d ATO inhibited EBV gene expression at both the RNA and protein levels. Mutu cells were treated with ATO at the indicated concentration for 3 days or with 0.5 nM ATO with/without $45 \mu$ M GCV and harvested for western blotting and real-time RT-PCR. ${ }^{*} p<0.05$ vs no treatment (NT)

middle), when treated with ATO for 3 days at the indicated concentrations. PML protein levels were reduced by ATO as expected. In addition, ATO inhibited EBV gene and PML expression in peripheral blood mononuclear cells (PBMC) infected with EBV in vitro (Fig. 1b right).

Co-treatment of ATO with ganciclovir $(\mathrm{GCV})$, a virus DNA replication inhibitor, decreased PML protein expression as well as that of the EBV BMRF1 in EBVpositive latency type I cells, Rael (Fig. 1c left) and SAV5 (Fig. 1c right). PMA was used as a positive control to induce the expression of the EBV lytic genes BMRF1 and Zta in Rael cells.

Mutu cells treated with various concentrations of ATO $(0.1-2 \mathrm{nM})$ for 3 days were harvested for western blotting and RT-PCR. ATO $(0.1 \mathrm{nM})$ inhibited the expression of the EBV immediate early gene Zta, along with other lytic genes including BMRF1, BGLF1 and VCA (Fig. 1d left). ATO treatment did not affect the mRNA level of the EBV latent gene LMP1. Zta mRNA expression was inhibited by $\mathrm{ATO}$ at $0.5 \mathrm{nM}$ and $1 \mathrm{nM}$ (Fig. 1d right). In contrast, the combination of ATO and ganciclovir blocked the expression of LMP1 mRNA.

\section{ATO inhibits EBV genome replication}

Downregulation of EBV lytic gene expression by ATO prompted investigation into the effects of ATO on EBV replication. To quantify EBV viral load, viral DNA was extracted from the media, in which the cells were cultured. 
Real-time PCR was performed to assess genomic DNA levels through detection of a region encompassing the EBV BamHI $\mathrm{Z}$ fragment. The viral genome level was low in ATO-treated cell media compared to untreated cell media, and co-treatment of ATO with GCV blocked the genome level even more dramatically (Fig. 2a). GCV alone also inhibited EBV genome levels. We also extracted total cellular DNA and viral DNA from ATO-treated EBV-positive Mutu (M), JY (J), BX-1(B) and Akata (A) cells (Fig. 2b) and quantified the viral genomic DNA (BamHI Z fragment and a region surrounding the EBNA1 Qp promoter). ATO inhibited viral DNA genome accumulation, indicating that

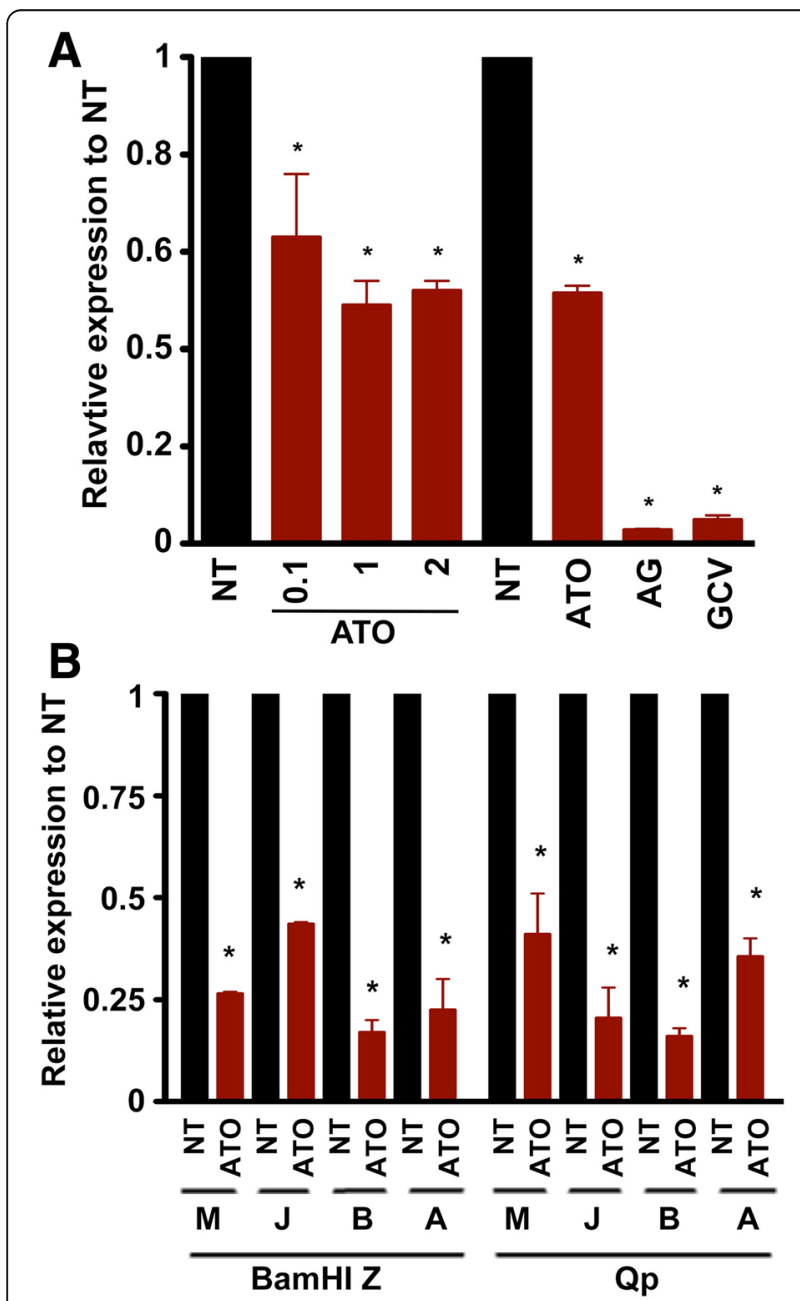

Fig. 2 ATO inhibits EBV genomic DNA replication. a Mutu cells were treated with $1 \mathrm{nM}$ of ATO for 3 days and cell media was harvested for viral genome extraction. PCR was performed using primers spanning the BamHI Z fragment of the EBV genome, ${ }^{*} p<0.05$ vs. NT. b EBVpositive cells, Mutu (M), JY (J), BX-1(B), and Akata (A) cells were treated with $1 \mathrm{nM}$ of ATO for 5 days and cellular total DNA was extracted for $\mathrm{PCR}$ using primers spanning the BamHI Z region and the $\mathrm{Qp}$ region of EBV genome, ${ }^{*} p<0.05$ vs. NT. The relative expression of BamHI $Z$ and Qp was calculated using the comparative $C t$ method $\left(2^{-\Delta \Delta C T}\right)$
ATO blocked EBV genome replication or decreased the EBV genomic DNA levels.

\section{ATO promotes greater cell death in EBV-positive cells than in EBV-negative cells ATO-induced cell death is dose- and time-dependent} To test the influence of ATO on cell viability, EBVpositive latency type I Akata, latency type II Cl13, and latency type III JY cells were treated with ATO at the indicated concentrations $(0.5 \mathrm{nM}-10 \mathrm{nM})$. Cell viability was measured daily via the trypan blue method. ATO decreased cell viability in a dosed-dependent manner (Fig. 3a). ATO induced cell death at $1 \mathrm{nM}$ in Akata and $2 \mathrm{nM}$ in Cl13 cells and $5 \mathrm{nM}$ in JY cells on day 3. Furthermore, the decrease in cell viability was dependent on the duration of ATO exposure. As shown in Fig. 3b, cell viability decreases by $15-30 \%$ at day 2 , but by day 4 viability was almost entirely lost.

To determine the viability of diffuse large B-cell lymphoma cells in response to ATO, diffuse large B-cell lymphoma cells (Farage) were treated with ATO at the indicated concentrations and cell viability was determined using trypan blue (Fig. 3c). Farage cell viability was decreased by approximately $50 \%$ after 2 days of treatment with $1 \mathrm{nM}$ of ATO, and was diminished further at a higher concentration $(10 \mathrm{nM})$ and longer treatment duration (4 days).

We did not observe any difference in cell viability in response to ganciclovir alone, indicating that ganciclovir cannot induce cell death in EBV-positive PBMC cells, diffuse large B-cell lymphoma cells (Farage), or other lymphoma cell lines (Mutu and Cl13) (Fig. 3d). Nevertheless, the combination of ganciclovir with ATO significantly decreased cell viability and induced much greater cell death compared the effect of ATO alone. ATO treatment resulted in a 50-70\% loss of cell viability compared to no treatment in CL13 and Mutu cells respectively and this effect was even more pronounced, specifically a $90 \%$ loss in cell viability, when ATO and ganciclovir were employed together for 3 days. PBMC and Farage cells also demonstrated enhanced sensitivity to the combination of ATO and ganciclovir. Viability was minimal in PBMC and Farage cells after 3 days of treatment with $10 \mathrm{nM}$ of ATO, alone or with ganciclovir.

\section{ATO specifically decreases EBV-positive cell viability and cell growth}

In this set of experiments, we assessed whether loss of cell viability with ATO or ATO/GCV is specific to EBVpositive lymphoma cells. EBV-positive Mutu (Mutu+)/ Akata (Akata+) and EBV-negative Mutu (Mutu-) / Akata (Akata-) cells were treated with ATO at the indicated concentrations for 3 days and cell viability was measured. As shown in Fig. 4a, cell viability decreased from 

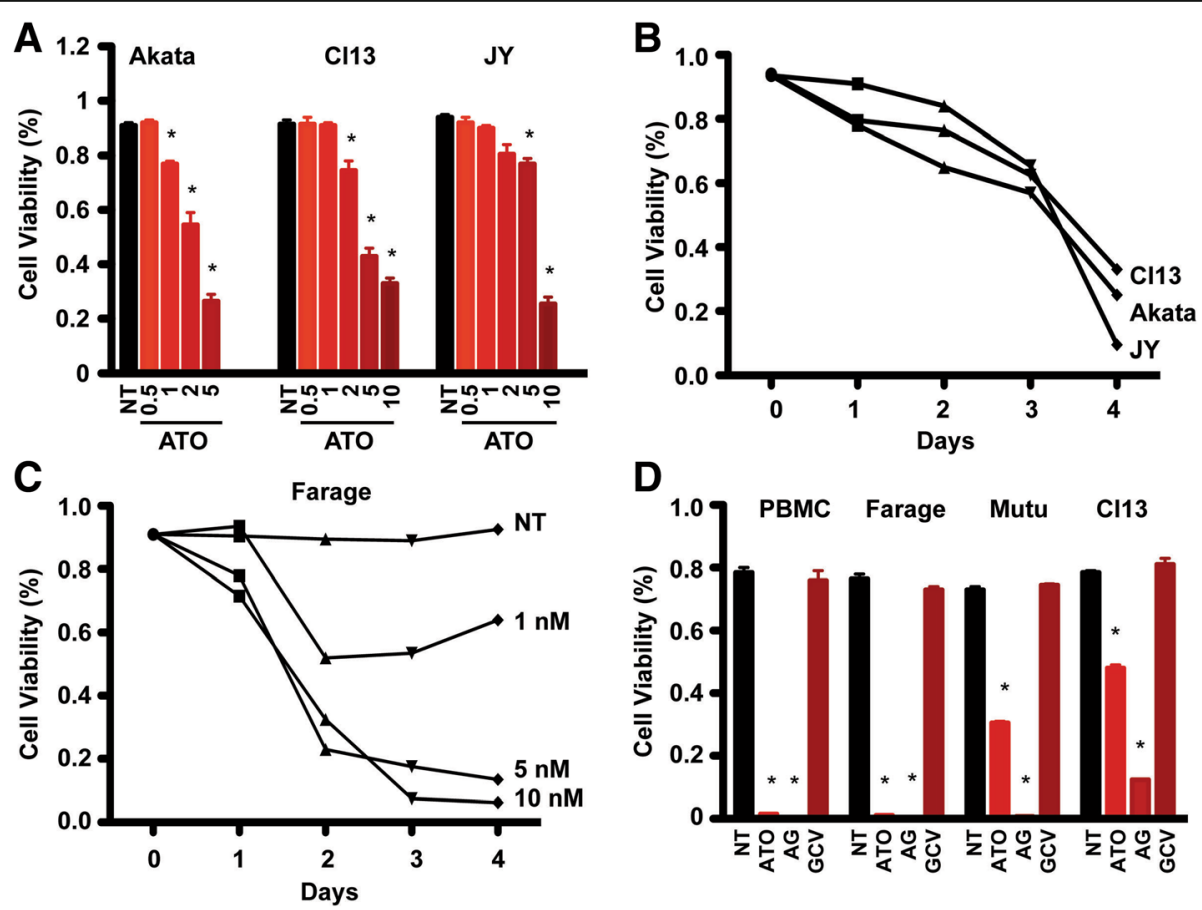

Fig. 3 ATO inhibited cell viability in a dose- and time-dependent manner. a EBV latency type I (Akata), type II (Cl13) and type III (JY) cells were treated with ATO for 3 days at the indicated concentrations $(0.5 \mathrm{nM}-10 \mathrm{nM})$ and cell viability was analyzed using a trypan blue method. * $p<0.05$ vs. no treatment (NT). $\mathbf{b}$ The time course analysis of cell viability in response to $2 \mathrm{nM}$ of ATO in EBV-positive cells. c The dose- and time-course analysis of cell viability after treatment with ATO in Farage cells. $\mathbf{d}$ The combination of ATO (10 nM) and ganciclovir (45 $\mu \mathrm{M})$ synergistically decreased cell viability on day 3 in EBV-positive cells. ${ }^{*}, p<0.05$ vs. NT

$90 \%$ viable cells to $53 \%$ viable cells in Akata + cells and from $92 \%$ viable cells to $65 \%$ viable cells in Mutu + cells at a $1 \mathrm{nM}$ concentration of ATO. Higher concentrations of ATO $(5 \mathrm{nM})$ decreased viability to 35 and $41 \%$ in Akata + and Mutu + respectively. Time course experiments employing an MTT assay demonstrated that ATO (1 $\mathrm{nM})$ decreased EBV-positive cell proliferation at day 1, which was also evident on day 3 (Fig. 4b). Compared to untreated cells, EBV-positive Akata cell growth was decreased by $16-42 \%$, and Mutu cell growth decreased by $20-38 \%$. In contrast, EBV-negative cell growth showed no significant change compared to untreated cells (Fig. 4b).

ATO inhibits EBV reactivation through ubiquitination and sumoylation pathways

We sought the mechanism through which ATO inhibits EBV gene expression. It is established that ATO degrades PML through SUMO-mediated ubiquitination $[53,54,64]$. To determine whether ATO inhibits EBV reactivation via the ubiquitin-mediated pathway, SUMO1 expression was assessed in response to ATO treatment in EBV-positive lymphoma cells. SUMO1 was increased at early time points, specifically $30 \mathrm{~min}$ and
$2 \mathrm{~h}$ after ATO treatment, indicating that ATO may promote EBV protein degradation through the SUMO1induced ubiquitin pathway (Fig. 5a). To further investigate this, the EBV gene Zta was immunoprecipitated from these samples and was observed to co-precipitate of ubiquitin. As shown in Fig. 5b, ubiquitin protein levels were higher in ATO-treated samples, indicating that ATO induced Zta-bound ubiquitin, and that Zta is ubiquitinated, which fosters its degradation. Taken together, these data suggest that ATO inhibits EBV protein expression via ubiquitin-mediated protein degradation.

To further test this hypothesis, inhibition experiments to block protein ubiquitination and sumoylation were performed by treating cells with the proteasome inhibitor MG132 and the protein sumoylation inhibitor Ginkgolic acid (GA). MG132 rescued ATO-mediated PML degradation as well as ATO-induced EBV protein degradation (Fig. $5 \mathrm{c}$ and d). PML protein expression was inhibited by ATO (1 nM) and MG132 rescued PML expression $(0.1 \mu \mathrm{M}$ for $16 \mathrm{~h}$ (Fig. $5 \mathrm{c}$ ) or $20 \mu \mathrm{M}$ for $4 \mathrm{~h}$ (Fig. 5d)). Interestingly, MG132 also recovered ATOmediated inhibition of EBV protein expression, specifically Zta, Rta and BMRF1 (Fig. 5c and d). MG132 alone did not affect EBV gene expression at $0.5 \mu \mathrm{M}$ for $16 \mathrm{~h}$, 

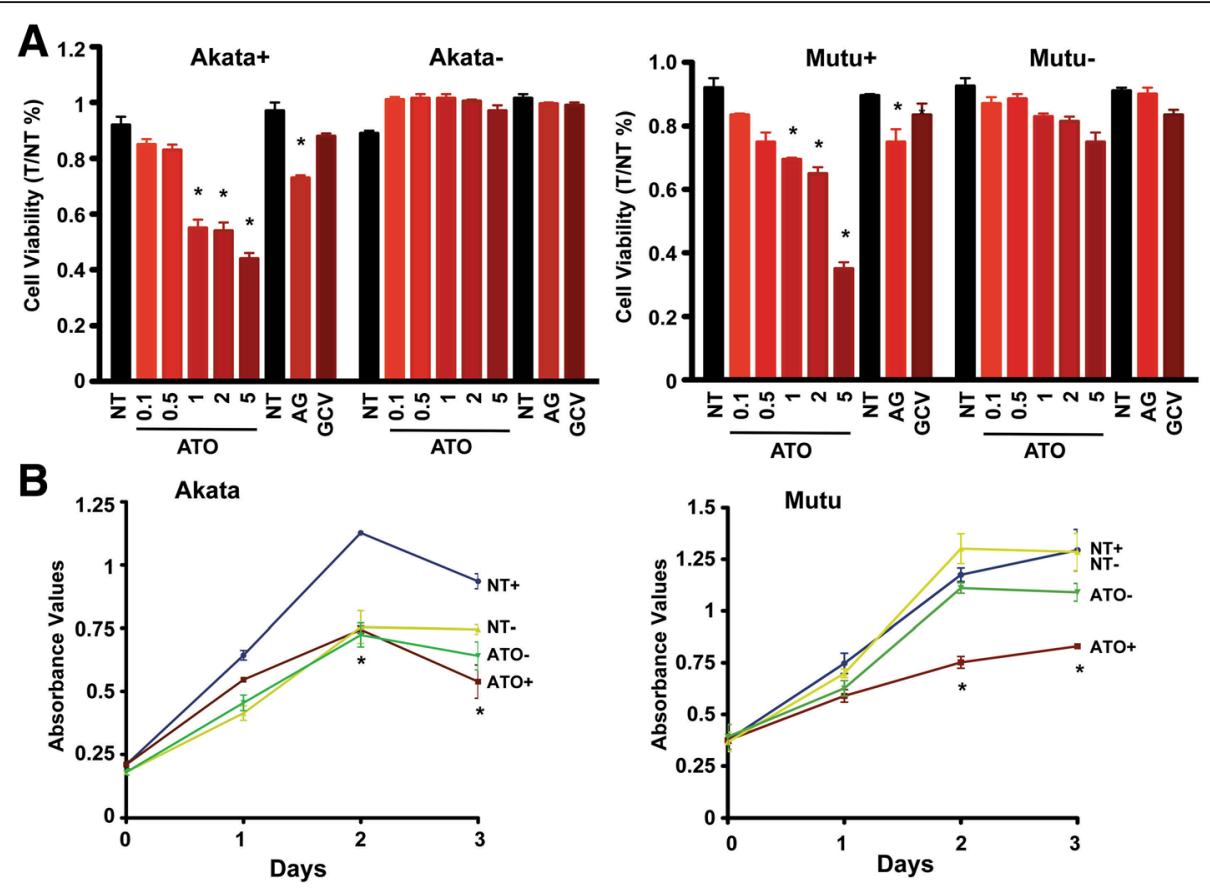

Fig. 4 ATO decreased cell viability and growth in EBV-positive cells but not in EBV-negative cells. a EBV-positive cells (Mutu+, Akata+) and EBVnegative cells (Mutu-, Akata-) were treated with ATO alone at the indicated concentrations ( $0.1 \mathrm{nM}-5 \mathrm{nM}$ ) or with $45 \mu \mathrm{M}$ of ganciclovir (GCV) for 3 days and cell viability was determined using trypan blue (AG indicates the combination of $0.5 \mathrm{nM}$ of ATO and $45 \mu \mathrm{M}$ of GCV). ${ }^{*} p<0.05$ vs no treatment (NT). $\mathbf{b}$ Mutu and Akata cells were treated with $1 \mathrm{nM}$ of ATO and a MTT assay was performed daily for 3 days (+ represents EBVpositive cells, - indicates EBV-negative cells, NT denote no treatment). ${ }^{*} p<0.05$ vs NT

implying that MG132 mediates EBV recovery from ATO through inhibiting EBV protein ubiquitination. Thus, ATO's effect on EBV protein expression is mediated through the proteasome ubiquitin pathway. To assess whether ATO-induced sumoylation is involved in EBV protein ubiquitination, cells were treated with ATO along with the protein sumoylation inhibitor Ginkgolic acid (Fig. 5d). EBV genes Zta, Rta and BMRF1, and the cellular protein PML, was inhibited by ATO, and notably inactivation of sumoylation using $10 \mu \mathrm{M}$ Ginkgolic acid for $4 \mathrm{~h}$ completely blocked their degradation. These observations provide supportive evidence that both sumoylation and ubiquitination contribute to ATO-induced EBV protein degradation.

To better understand the ATO-induced EBV lytic protein degradation pathway, a series of combination treatments were performed in EBV-positive latency type I cells. EBV reactivation by BCR signaling (anti-IgM), protein kinase $\mathrm{C}$ activation [1] and TGF- $\beta$ signaling provide unique models to investigate ATO-mediated EBV protein degradation. First, a combination of ATO with each of these signaling reagents was applied to cells, and the proteasome inhibitor MG132 was added prior to harvest. As shown in Fig. 5e, ATO inhibited anti-IgM-, PMA- and TGF- $\beta$-mediated EBV reactivation. The expression of Zta, Rta and BMRF1 were activated by anti-IgM, PMA or TGF- $\beta$, and inhibited after cotreatment with ATO. Importantly, MG132 rescued the
ATO-mediated inhibition of EBV reactivation induced by anti-IgM, PMA or TGF- $\beta$ (Fig. 5e). Therefore, ATO disrupts the EBV infection cycle and inhibits EBV gene expression through activation of global cellular protein ubiquitination. These results indicate that ATO induces the rapid sumoylation of Zta, Rta and BMRF1, resulting in their ubiquitination and proteasome-dependent degradation. Thus, ATO-mediated EBV protein degradation is dependent on SUMO-regulated protein ubiquitination and proteasomemediated degradation.

\section{Discussion}

We have shown that ATO inhibits EBV reactivation through ubiquitin-mediated degradation. The consequences of this were inhibition of EBV replication and induction of cell death in EBV-positive cells. This result is consistent with a previous report that loss of the EBV genome and lytic gene expression leads to the loss of the malignant phenotype and cell viability in EBV-positive Burkitt's lymphoma cells [65-67]. EBV lytic genes are expressed in $29 \%$ of lymphoma patients according to Dr. Liu's report [67]. In EBV-positive cells, the lytic viral proteins regulate diverse homeostatic cellular functions including inflammation and angiogenesis. Thus, the small portion of cells in the lytic cycle may support tumor cell growth and survival by providing cell growth factors and other signals. Diminishing lytic gene expression in cells 


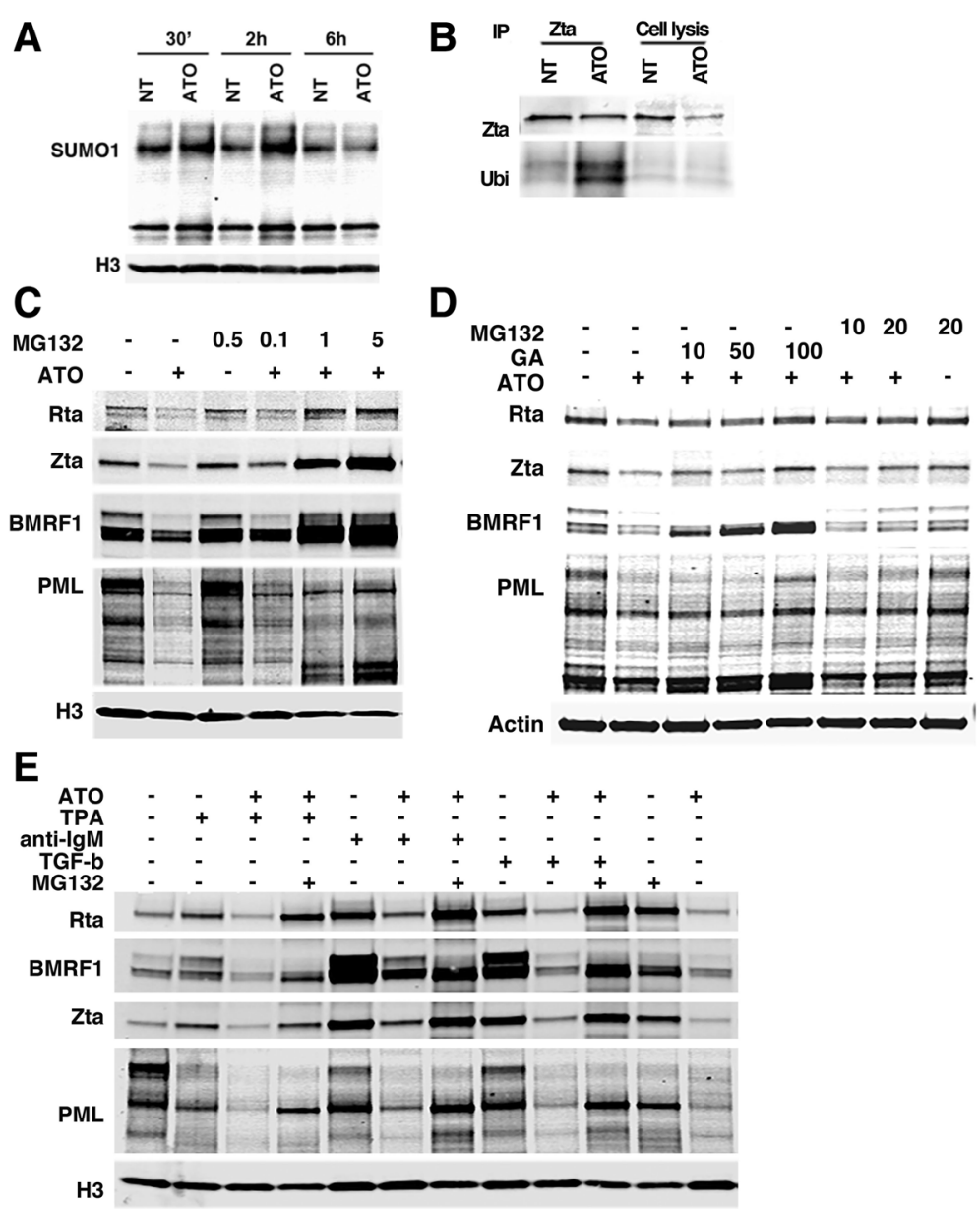

Fig. 5 EBV lytic proteins were ubiquitined and sumoylated in response to ATO treatment and this effect was rescued using proteasome and SUMO inhibitors in EBV latency type I Mutu cells. a $1 \mathrm{nM}$ of ATO induced SUMO1 expression. b Co-IP with antibodies against Zta and western blotting using antibodies against ubiquitin. c MG132 at various concentrations (0.1 $\mathrm{MM}-5 \mu \mathrm{M}$ for $16 \mathrm{~h})$ rescued EBV spontaneous reactivation that was reduced in response to $1 \mathrm{nM}$ of ATO. $\mathbf{d}$ Proteasome (MG132) \& SUMO1 (Ginkgolic Acid, GA) inhibitors rescued the reduction in EBV reactivation in response to ATO. Cells were treated with $1 \mathrm{nM}$ of ATO for 3 days and with/without MG132 or GA at indicated concentrations ( $\mu$ M) for 4 h. e 1 nM ATO inhibited the anti-IgM-, PMA-, and TGF- $\beta$-induced EBV reactivation and MG132 (1 $\mu \mathrm{M}$ for $16 \mathrm{~h}$ ) abrogated this effect

exposed to ATO eradicates EBV genome replication and results EBV-dependent cell death.

Spontaneous EBV reactivation provides us a cell system to evaluate the anti-tumor effect of ATO on lymphoma cells. The expression of EBV lytic genes is decreased significantly in response to ATO treatment, suggesting that ATO promotes EBV lytic protein degradation (Fig. 1). Further, the growth rate in cell populations with spontaneous EBV reactivation is faster than in cells treated with ATO. More importantly, inhibiting EBV lytic gene expression in cells exposed to ATO impedes the proliferation of these cells (Figs. 3 \& 4), but this was not observed in EBV-negative cells. In EBV-associated lymphomas and other tumors, spontaneous reactivation is thought to play an important oncogenic role [67, 68], and using reagents to inhibit EBV lytic gene expression reduces EBV-positive cell viability [67]. The above evidence adds support to the idea that
ATO could serve a therapeutic agent for EBV-positive lymphomas.

On the other hand, lytic induction by reagents in vitro eventually leads to a more persistent latent stage, which induces other oncogenes that may foster the development of malignancies. Thus, the major concern is that lytic induction by chemotherapy is also followed by stages of latency. Treatment of Akata and Mutu cells with anti-IgG or anti IgM induces latent gene expression [69]. Moreover, Akata cells remain viable much longer after treatment. Also, co-expression of lytic replication and latency proteins has been detected in vivo [70, 71]. Though lytic induction therapy looks promising, its toxicity and side effects cannot be avoided, and it may lead to more persistent latent infection. Thus, the combination of ATO with lytic inducers is a possible alternative strategy for anti-EBV associated lymphomas. 
The presence of EBV lytic cycle replication in these cells promotes the expression of BGLF4 (Fig. 1d), which is a viral-encoded protein kinase that phosphorylates ganciclovir to its active form (monophosphorylated) [72]. The phosphorylated ganciclovir incorporates with viral and cellular DNA and kills the cells via disrupting replication [73], providing a plausible explanation for the diminished EBV gene expression in response to ganciclovir. However, due to the low level of BGLF4 necessary for converting the ganciclovir into its active form, it cannot independently induce significant cell death.

The circular EBV chromosome replicates once with each cell division and depends on cellular replication machinery during the latent stage [74], whereas EBV-encoded lytic genes drive EBV lytic replication and yields numerous copies of viral genomes within each cell. As a lytic transactivator, Zta binds to the lytic replication origins (oriLyt) and activates the other EBV lytic genes to initiate EBV lytic replication. Zta recruits the EBV core replication machinery and other cellular proteins into the oriLyt region to initiates EBV lytic replication after Zta binds to EBV oriLyt. Thus, inhibition of Zta or other related EBV lytic replication factors would eradicate the EBV episomal genome. Moreover, as a transcription activator, Zta is required for the transcriptional activation of its own promoter BZLF1 [75], as well as the promoters of other lytic genes such as BRLF1, BMRF1 and BALF2 (the major DNA-binding proteins) [3, 76-78]. Thus, reduction of Zta expression would be expected to reduce Rta, BMRF1 and BALF2 expression, and further diminish Zta expression. Hence, inhibition of Zta expression or Zta transcriptional activity decreases not only EBV lytic gene expression but also the production of the EBV episomal genome. This explains why EBV gene expression and the EBV genome are decreased after ATO treatment as shown in Figs. $1 \& 2$.

Arsenic activates EBV reactivation in epithelial cells (NPC-KT) [12], but inhibits EBV lytic genes expression in lymphoma cells. This may be due to differences between anchored epithelia cells in comparison to lymphoma cells in suspension. Cell signaling is different between these two cell types. For example, the oncoprotein c-Myc is overexpressed and translocated in most lymphomas. C-Myc not only regulates cell biological function but is also involved with sumoylation regulators, such as SUMO2/3 and E1/2/3 ligases [79], which are in turn regulated by arsenic and contribute to degradation of EBV lytic gene expression in lymphoma cells. In contrast, NPC-KT cells are EBV latency type II cells that express the EBV latent genes LMP2A and LMP1, which can interact with the ubiquitin/proteasome system to regulate gene expression $[80,81]$. These interactions could interfere with arsenic's modulation of the ubiquitin pathway and curb arsenic's effects on EBV lytic gene expression.

Our results show that ATO not only blocks EBV spontaneous reactivation but also reagent-induced reactivation (Fig. 5e), implying that ATO-inhibited EBV lytic gene expression occurs through a broadly utilized pathway. Proteasome or sumoylation inhibitors rescue the ATO-mediated reduction of EBV reactivation in a dose dependent manner. Furthermore, the co-immunoprecipitation experiment reveals that ATO leads to greater ubiquitinization of the Zta protein. Thus, these results indicate that ATO induces EBV lytic protein ubiquitination and proteasome-mediated degradation, and that sumoylation may facilitate the degradation process. On the basis of our observations, we propose the molecular mechanistic model for arsenic-mediated

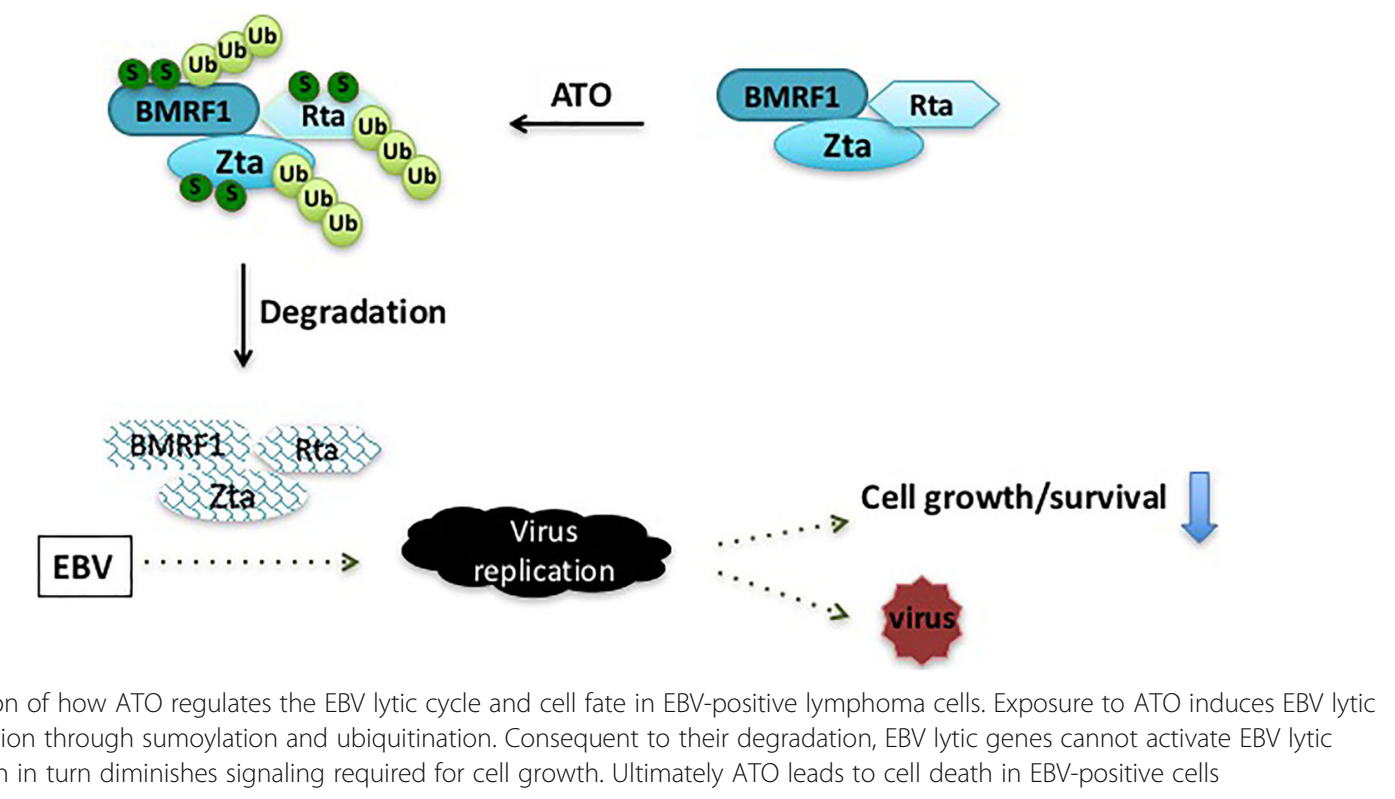

Fig. 6 A depiction of how ATO regulates the EBV lytic cycle and cell fate in EBV-positive lymphoma cells. Exposure to ATO induces EBV lytic protein degradation through sumoylation and ubiquitination. Consequent to their degradation, EBV lytic genes cannot activate EBV lytic replication, which in turn diminishes signaling required for cell growth. Ultimately ATO leads to cell death in EBV-positive cells 
degradation of EBV lytic genes and cell death in EBV-positive lymphoma cells illustrated in Fig. 6. Lytic gene expression will lead to cellular protein expression that provides signals for cell growth and tumorigenesis. In the presence of ATO, spontaneous and reagent-induced EBV reactivation is abolished, and involves decreased expression of EBV lytic genes by degradation of Zta, Rta and BMRF1 via sumoylation and ubiquitination. As a result, EBV cannot provide sufficient cell survival factors and results to cell death.

\section{Conclusions}

Most antiviral drugs have limited efficacy for treating EBV-related malignancies. ATO has received prior recognition as a cancer therapy due to its effectiveness in treating acute promyelocytic leukemia [47]. Several studies have shown that ATO may be useful for the treatment of other cancers such as ovarian, brain, breast, lung, gastric and cervical cancers [82-87]. However, its potential for the treatment of lymphoma has not been previously advanced. Our data suggests that ATO may be an effective therapeutic drug for EBV-specific lymphomas. We believe the mechanism by which ATO induces EBV gene ubiquitination and degradation requires further investigation, and in vivo murine tumor xenograft experiments will be prudent prior to clinic trials in humans.

\section{Acknowledgements}

We would like to thank Yan Zhuang, Dr. Chunmin Dong and Rafael Gongora for their technical assistance. Suggestion given by Dr. Fayong Luo has been a great help in arsenic treatment.

\section{Funding}

This research was supported by US National Institutes of Health Ruth L. Kirschstein National Research Service Awards 5T32HL007973 (Q.Y.) and the Ladies Leukemia League (J.A.L.).

\section{Availability of data and materials}

Not applicable.

\section{Authors' contributions}

QY designed and conducted the experiments of viral DNA extraction, MTT assay, western blotting and real time RT-PCR. QY also performed data analysis and wrote the manuscript. MS performed the ATO preparation and treatment. EKF and CHP provided invaluable expertise and suggestions regarding experiments design and reagents, and participated in data interpretation. JAL conceived of this project and was instrumental in experimental design and data interpretation. JAL also assisted with writing and editing the manuscript. All authors read and approved the final manuscript.

\section{Competing interests}

The authors declare that they have no competing interests.

\section{Consent for publication}

Not applicable.

Ethics approval and consent to participate

Not applicable.

\section{Publisher's Note}

Springer Nature remains neutral with regard to jurisdictional claims in published maps and institutional affiliations.

\section{Author details}

'Department of Medicine, Section of Pulmonary Disease, Tulane University School of Medicine, 1430 Tulane Ave, New Orleans, LA 70112, USA.

${ }^{2}$ Department of Internal Medicine, Louisiana University School of Medicine, 1901 Perdido Street, New Orleans, LA 70112, USA. ${ }^{3}$ Department of Pathology and Laboratory, Tulane University School of Medicine, 1430 Tulane Ave, New Orleans, LA 70112, USA. ${ }^{4}$ Department of Internal Medicine, University of Texas Medical Branch, 300 University Blvd, Galveston, TX 77550, USA.

Received: 19 January 2017 Accepted: 12 June 2017

Published online: 21 June 2017

\section{References}

1. Duijster JW, Goorhuis A, van Genderen PJ, Visser LG, Koopmans MP, Reimerink $\mathrm{JH}$, et al. Zika virus infection in 18 travellers returning from Surinam and the Dominican Republic, The Netherlands, November 2015March 2016. Infection. 2016;44:797.

2. Borras AM, Strominger JL, Speck SH. Characterization of the ZI domains in the Epstein-Barr virus BZLF1 gene promoter: role in phorbol ester induction. J Virol. 1996:70(6):3894-901.

3. Yin Q, Jupiter K, Flemington EK. The Epstein-Barr virus transactivator Zta binds to its own promoter and is required for full promoter activity during anti-lg and TGF-beta1 mediated reactivation. Virology. 2004;327(1):134-43.

4. Rodriguez A, Jung EJ, Flemington EK. Cell cycle analysis of Epstein-Barr virus-infected cells following treatment with lytic cycle-inducing agents. J Virol. 2001;75(10):4482-9.

5. Wittmann P, Hofler P, Bauer G. Epstein-barr virus induction by a serum factor: IV. Ubiquitous occurrence of the factor within vertebrates and its interaction with defined lymphoid cell lines. Int J Cancer. 1982;30(4):503-10.

6. Bauer $\mathrm{G}$. Induction of Epstein-Barr virus early antigens by corticosteroids: inhibition by TPA and retinoic acid. Int J Cancer. 1983:31(3):291-5.

7. Jiang JH, Wang N, Li A, Liao WT, Pan ZG, Mai SJ, et al. Hypoxia can contribute to the induction of the Epstein-Barr virus (EBV) Iytic cycle. J Clin Virol. 2006;37(2):98-103.

8. Yin Q, Wang X, Fewell C, Cameron J, Zhu H, Baddoo M, et al. MicroRNA miR-155 inhibits bone morphogenetic protein (BMP) signaling and BMPmediated Epstein-Barr virus reactivation. J Virol. 2010;84(13):6318-27.

9. Cayrol C, Flemington EK. Identification of cellular target genes of the Epstein-Barr virus transactivator Zta: activation of transforming growth factor beta igh3 (TGF-beta igh3) and TGF-beta 1. J Virol. 1995;69(7):4206-12.

10. Chasserot-Golaz S, Schuster C, Dietrich JB, Beck G, Lawrence DA. Antagonistic action of RU38486 on the activity of transforming growth factor-beta in fibroblasts and lymphoma cells. J Steroid Biochem. 1988:30(1-6):381-5.

11. Dietrich JB, Chasserot-Golaz S, Beck G, Bauer G. Antagonism of glucocorticoid induction of Epstein-Barr virus early antigens by different steroids in Daudi lymphoma cells. J Steroid Biochem. 1986;24(1):417-21.

12. Sides MD, Sosulski ML, Luo F, Lin Z, Flemington EK, Lasky JA. Co-treatment with arsenic trioxide and ganciclovir reduces tumor volume in a murine xenograft model of nasopharyngeal carcinoma. Virol J. 2013;10:152.

13. Hickey JM, Keane MG, Kenny DA, Cromie AR, Mulder HA, Veerkamp RF. Estimation of accuracy and bias in genetic evaluations with genetic groups using sampling. J Anim Sci. 2008;86(5):1047-56.

14. Lo YM. Quantitative analysis of Epstein-Barr virus DNA in plasma and serum: applications to tumor detection and monitoring. Ann N Y Acad Sci. 2001;945:68-72

15. Hong GK, Gulley ML, Feng WH, Delecluse HJ, Holley-Guthrie E, Kenney SC. Epstein-Barr virus lytic infection contributes to lymphoproliferative disease in a SCID mouse model. J Virol. 2005;79(22):13993-4003.

16. Asito AS, Piriou E, Odada PS, Fiore N, Middeldorp JM, Long C, et al. Elevated anti-Zta lgG levels and EBV viral load are associated with site of tumor presentation in endemic Burkitt's lymphoma patients: a case control study. Infect Agent Cancer. 2010;5:13

17. Luka J, Deeb ZE, Hartmann DP, Jenson B, Pearson GR. Detection of antigens associated with Epstein-Barr virus replication in extracts from biopsy specimens of nasopharyngeal carcinomas. J Natl Cancer Inst. 1988;80(14):1164-7. 
18. Fang CY, Huang SY, Wu CC, Hsu HY, Chou SP, Tsai CH, et al. The synergistic effect of chemical carcinogens enhances Epstein-Barr virus reactivation and tumor progression of nasopharyngeal carcinoma cells. PLoS One. 2012;7(9):e44810.

19. Suzuki R, Yamaguchi M, Izutsu K, Yamamoto G, Takada K, Harabuchi Y, et al. Prospective measurement of Epstein-Barr virus-DNA in plasma and peripheral blood mononuclear cells of extranodal NKT-cell lymphoma, nasal type. Blood. 2011;118(23):6018-22.

20. Lei Kl, Chan LY, Chan WY, Johnson PJ, Lo YM. Diagnostic and prognostic implications of circulating cell-free Epstein-Barr virus DNA in natural killer/Tcell lymphoma. Clin Cancer Res. 2002;8(1):29-34

21. Wang ZY, Liu QF, Wang H, Jin J, Wang WH, Wang SL, et al. Clinical implications of plasma Epstein-Barr virus DNA in early-stage extranodal nasal-type NKT-cell lymphoma patients receiving primary radiotherapy. Blood. 2012;120(10):2003-10.

22. Mauser A, Holley-Guthrie E, Zanation A, Yarborough W, Kaufmann W, Klingelhutz $A$, et al. The Epstein-Barr virus immediate-early protein BZLF induces expression of E2F-1 and other proteins involved in cell cycle progression in primary keratinocytes and gastric carcinoma cells. J Virol. 2002;76(24):12543-52.

23. Mauser A, Saito S, Appella E, Anderson CW, Seaman WT, Kenney S. The Epstein-Barr virus immediate-early protein BZLF1 regulates p53 function through multiple mechanisms. J Virol. 2002;76(24):12503-12.

24. Sato Y, Shirata N, Kudoh A, Iwahori S, Nakayama S, Murata T, et al. Expression of Epstein-Barr virus BZLF1 immediate-early protein induces p53 degradation independent of MDM2, leading to repression of p53-mediated transcription. Virology. 2009;388(1):204-11.

25. Sato Y, Shirata N, Murata T, Nakasu S, Kudoh A, Iwahori S, et al. Transient increases in p53-responsible gene expression at early stages of Epstein-Barr virus productive replication. Cell Cycle. 2010;9(4):807-14.

26. Sato Y, Kamura T, Shirata N, Murata T, Kudoh A, Iwahori S, et al. Degradation of phosphorylated p53 by viral protein-ECS E3 ligase complex. PLoS Pathog. 2009;5(7):e1000530.

27. Hsu M, Wu SY, Chang SS, Su IJ, Tsai CH, Lai SJ, et al. Epstein-Barr virus lytic transactivator Zta enhances chemotactic activity through induction of interleukin-8 in nasopharyngeal carcinoma cells. J Virol. 2008;82(7):3679-88.

28. Mahot S, Sergeant A, Drouet E, Gruffat H. A novel function for the EpsteinBarr virus transcription factor EB1/Zta: induction of transcription of the hIL10 gene. J Gen Virol. 2003;84(Pt 4):965-74.

29. Tsai SC, Lin SJ, Chen PW, Luo WY, Yeh TH, Wang HW, et al. EBV Zta protein induces the expression of interleukin-13, promoting the proliferation of EBVinfected B cells and lymphoblastoid cell lines. Blood. 2009;114(1):109-18.

30. Lan YY, Yeh TH, Lin WH, Wu SY, Lai HC, Chang FH, et al. Epstein-Barr virus Zta upregulates matrix metalloproteinases 3 and 9 that synergistically promote cell invasion in vitro. PLoS One. 2013;8(2):e56121.

31. Lu J, Chua HH, Chen SY, Chen JY, Tsai CH. Regulation of matrix metalloproteinase-1 by Epstein-Barr virus proteins. Cancer Res. 2003;63(1):256-62.

32. Komano J, Maruo S, Kurozumi K, Oda T, Takada K. Oncogenic role of Epstein-Barr virus-encoded RNAs in Burkitt's lymphoma cell line Akata. J Virol. 1999;73(12):9827-31.

33. Hughes DJ, Dickerson CA, Shaner MS, Sample CE, Sample JT. Transrepression of protein expression dependent on the Epstein-Barr virus promoter Wp during latency. J Virol. 2011;85(21):11435-47.

34. Kennedy G, Komano J, Sugden B. Epstein-Barr virus provides a survival factor to Burkitt's lymphomas. Proc Natl Acad Sci U S A. 2003;100(24):14269-74.

35. Ruf IK, Rhyne PW, Yang C, Cleveland JL, Sample JT. Epstein-Barr virus small RNAs potentiate tumorigenicity of Burkitt lymphoma cells independently of an effect on apoptosis. J Virol. 2000;74(21):10223-8.

36. Ruf IK, Rhyne PW, Yang H, Borza CM, Hutt-Fletcher LM, Cleveland JL, et al. Epstein-barr virus regulates c-MYC, apoptosis, and tumorigenicity in Burkitt lymphoma. Mol Cell Biol. 1999;19(3):1651-60.

37. Komano J, Sugiura M, Takada K. Epstein-Barr virus contributes to the malignant phenotype and to apoptosis resistance in Burkitt's lymphoma cell line Akata. J Virol. 1998;72(11):9150-6.

38. Shannon-Lowe C, Adland E, Bell Al, Delecluse HJ, Rickinson AB, Rowe M. Features distinguishing Epstein-Barr virus infections of epithelial cells and $B$ cells: viral genome expression, genome maintenance, and genome amplification. J Virol. 2009;83(15):7749-60.

39. Schepers A, Pich D, Hammerschmidt W. Activation of oriLyt, the lytic origin of DNA replication of Epstein-Barr virus, by BZLF1. Virology. 1996;220(2):367-76
40. Neuhierl B, Delecluse HJ. The Epstein-Barr virus BMRF1 gene is essential for lytic virus replication. J Virol. 2006;80(10):5078-81.

41. Fixman ED, Hayward GS, Hayward SD. Replication of Epstein-Barr virus oriLyt: lack of a dedicated virally encoded origin-binding protein and dependence on Zta in cotransfection assays. J Virol. 1995;69(5):2998-3006.

42. Flamand L, Stefanescu I, Ablashi DV, Menezes J. Activation of the Epstein-Barr virus replicative cycle by human herpesvirus 6. J Virol. 1993;67(11):6768-77.

43. Fixman ED, Hayward GS, Hayward SD. Trans-acting requirements for replication of Epstein-Barr virus ori-Lyt. J Virol. 1992;66(8):5030-9.

44. Zhang Q, Hong Y, Dorsky D, Holley-Guthrie E, Zalani S, Elshiekh NA, et al. Functional and physical interactions between the Epstein-Barr virus (EBV) proteins BZLF1 and BMRF1: effects on EBV transcription and lytic replication. J Virol. 1996;70(8):5131-42.

45. Liao G, Wu FY, Hayward SD. Interaction with the Epstein-Barr virus helicase targets Zta to DNA replication compartments. J Virol. 2001;75(18):8792-802.

46. Baumann M, Feederle R, Kremmer E, Hammerschmidt W. Cellular transcription factors recruit viral replication proteins to activate the Epstein-Barr virus origin of lytic DNA replication, oriLyt. EMBO J. 1999;18(21):6095-105.

47. Vidal G, Blanchi T, Mieszawska AJ, Calabrese R, Rossi C, Vigneron P, et al. Enhanced cellular adhesion on titanium by silk functionalized with titanium binding and RGD peptides. Acta Biomater. 2013;9(1):4935-43.

48. Chen GQ, Shi XG, Tang W, Xiong SM, Zhu J, Cai X, et al. Use of arsenic trioxide (As2O3) in the treatment of acute promyelocytic leukemia (APL) .1. As203 exerts dose-dependent dual effects on APL cells. Blood. 1997:89(9):3345-53.

49. Chen Z, Chen GO, Shi XG, Tang W, Zhu J, Xiong SM, et al. Use of arsentic trioxide (As2O3) in the treatment of acute promyelocytic leukemia (APL) .1. Arsenic causes both apoptosis and partial differentiation of NB4 and fresh APL cells in vitro and in vivo. Blood. 1996;88(10):864.

50. Shen ZX, Chen GQ, Ni JH, Li XS, Xiong SM, Qiu QY, et al. Use of arsenic trioxide (As2O3) in the treatment of acute promyelocytic leukemia (APE) .2. Clinical efficacy and pharmacokinetics in relapsed patients. Blood. 1997:89(9):3354-60.

51. Zhang $P$. The use of arsenic trioxide (As2O3) in the treatment of acute promyelocytic leukemia. J Biol Regul Homeost Agents. 1999;13(4):195-200.

52. Hands KJ, Cuchet-Lourenco D, Everett RD, Hay RT. PML isoforms in response to arsenic: high-resolution analysis of PML body structure and degradation. J Cell Sci. 2014;127(Pt 2):365-75.

53. Zhang XW, Yan XJ, Zhou ZR, Yang FF, Wu ZY, Sun HB, et al. Arsenic trioxide controls the fate of the PML-RARalpha oncoprotein by directly binding PML. Science. 2010;328(5975):240-3.

54. Lallemand-Breitenbach $V$, Jeanne M, Benhenda S, Nasr R, Lei M, Peres L, et al. Arsenic degrades PML or PML-RARalpha through a SUMO-triggered RNF4/ubiquitin-mediated pathway. Nat Cell Biol. 2008;10(5):547-55.

55. Hagemeier SR, Dickerson SJ, Meng Q, Yu XM, Mertz JE, Kenney SC. Sumoylation of the Epstein-Barr virus BZLF1 protein inhibits its transcriptional activity and is regulated by the virus-encoded protein Kinase. J Virol. 2010;84(9):4383-94.

56. Adamson AL, Kenney S. Epstein-barr virus immediate-early protein BZLF1 is SUMO-1 modified and disrupts promyelocytic leukemia bodies. J Virol. 2001; 75(5):2388-99.

57. Chang LK, Lee YH, Cheng TS, Hong YR, Lu PJ, Wang JJ, et al. Post-translational modification of Rta of Epstein-Barr virus by SUMO-1. J Biol Chem. 2004;279(37):38803-12

58. Yang YC, Yoshikai Y, Hsu SW, Saitoh H, Chang LK. Role of RNF4 in the ubiquitination of Rta of Epstein-Barr virus. J Biol Chem. 2013;288(18):12866-79.

59. Adamson AL, Chohan K, Swenson J, LaJeunesse D. A drosophila model for genetic analysis of influenza viral/host interactions. Genetics. 2011;189(2):495-506.

60. Amon W, White RE, Farrell PJ. Epstein-Barr virus origin of lytic replication mediates association of replicating episomes with promyelocytic leukaemia protein nuclear bodies and replication compartments. J Gen Virol. 2006;87(Pt 5):1133-7.

61. Wang WH, Kuo CW, Chang LK, Hung CC, Chang TH, Liu ST. Assembly of Epstein-Barr virus capsid in promyelocytic leukemia nuclear bodies. J Virol. 2015;89(17):8922-31.

62. Yin Q, Flemington EK. siRNAs against the Epstein Barr virus latency replication factor, EBNA1, inhibit its function and growth of EBV-dependent tumor cells. Virology. 2006;346(2):385-93. 
63. Yin Q, Wang X, McBride J, Fewell C, Flemington E. B-cell receptor activation induces BIC/miR-155 expression through a conserved AP-1 element. J Biol Chem. 2008;283(5):2654-62.

64. Geoffroy MC, Jaffray EG, Walker KJ, Hay RT. Arsenic-induced SUMOdependent recruitment of RNF4 into PML nuclear bodies. Mol Biol Cell. 2010;21(23):4227-39.

65. Shimizu N, Tanabe-Tochikura A, Kuroiwa Y, Takada K. Isolation of EpsteinBarr virus (EBV)-negative cell clones from the EBV-positive Burkitt's lymphoma (BL) line Akata: malignant phenotypes of BL cells are dependent on EBV. J Virol. 1994;68(9):6069-73.

66. De Leo A, Arena G, Stecca C, Raciti M, Mattia E. Resveratrol inhibits proliferation and survival of Epstein Barr virus-infected Burkitt's lymphoma cells depending on viral latency program. Mol Cancer Res. 2011;9(10):1346-55.

67. Liu S, Li H, Chen L, Yang L, Li L, Tao Y, et al. (-)-Epigallocatechin-3-gallate inhibition of Epstein-Barr virus spontaneous lytic infection involves ERK1/2 and PI3-K/Akt signaling in EBV-positive cells. Carcinogenesis. 2013;34(3):627-37.

68. Geser A, de The $G$, Lenoir $G$, Day NE, Williams EH. Final case reporting from the Ugandan prospective study of the relationship between EBV and Burkitt's lymphoma. Int J Cancer. 1982;29(4):397-400.

69. Yuan J, Cahir-McFarland E, Zhao B, Kieff E. Virus and cell RNAs expressed during Epstein-Barr virus replication. J Virol. 2006;80(5):2548-65.

70. Webster-Cyriaque J, Middeldorp J, Raab-Traub N. Hairy leukoplakia: an unusual combination of transforming and permissive Epstein-Barr virus infections. J Virol. 2000;74(16):7610-8.

71. Yin Q, Wang X, Roberts C, Flemington EK, Lasky JA. Methylation status and AP1 elements are involved in EBV-mediated miR-155 expression in EBV positive lymphoma cells. Virology. 2016;494:158-67.

72. Meng Q, Hagemeier SR, Fingeroth JD, Gershburg E, Pagano JS, Kenney SC. The Epstein-Barr virus (EBV)-encoded protein kinase, EBV-PK, but not the thymidine kinase (EBV-TK), is required for ganciclovir and acyclovir inhibition of lytic viral production. J Virol. 2010;84(9):4534-42.

73. Keever-Taylor CA, Behn B, Konings S, Orentas R, Davies B, Margolis D. Suppression of EBV release from irradiated B lymphoblastoid cell-lines: superior activity of ganciclovir compared with acyclovir. Cytotherapy. 2003;5(4):323-35.

74. Klein G. Role of EBV and $\mathrm{lg} /$ myc translocation in Burkitt lymphoma. Antibiot Chemother. 1994;46:110-6.

75. Flemington EK, Lytle JP, Cayrol C, Borras AM, Speck SH. DNA-bindingdefective mutants of the Epstein-Barr virus lytic switch activator Zta transactivate with altered specificities. Mol Cell Biol. 1994;14(5):3041-52.

76. Liu P, Speck SH. Synergistic autoactivation of the Epstein-Barr virus immediate-early BRLF1 promoter by Rta and Zta. Virology. 2003;310(2):199-206.

77. Yang PW, Chang SS, Tsai CH, Chao YH, Chen MR. Effect of phosphorylation on the transactivation activity of Epstein-Barr virus BMRF1, a major target of the viral BGLF4 kinase. J Gen Virol. 2008;89(Pt 4):884-95.

78. Rennekamp AJ, Lieberman PM. Initiation of Epstein-Barr virus lytic replication requires transcription and the formation of a stable RNA-DNA hybrid molecule at OriLyt. J Virol. 2011;85(6):2837-50.

79. Busch K, Keller T, Fuchs U, Yeh RF, Harbott J, Klose I, et al. Identification of two distinct MYC breakpoint clusters and their association with various IGH breakpoint regions in the $\mathrm{t}(8 ; 14)$ translocations in sporadic Burkittlymphoma. Leukemia. 2007;21(8):1739-51.

80. Winberg G, Matskova L, Chen F, Plant P, Rotin D, Gish G, et al. Latent membrane protein 2A of Epstein-Barr virus binds WW domain E3 proteinubiquitin ligases that ubiquitinate B-cell tyrosine kinases. Mol Cell Biol. 2000; 20(22):8526-35.

81. Aviel S, Winberg G, Massucci M, Ciechanover A. Degradation of the epsteinbarr virus latent membrane protein 1 (LMP1) by the ubiquitin-proteasome pathway. Targeting via ubiquitination of the N-terminal residue. J Biol Chem. 2000;275(31):23491-9.

82. Kim J, Lee JJ, Kim J, Gardner D, Beachy PA. Arsenic antagonizes the hedgehog pathway by preventing ciliary accumulation and reducing stability of the Gli2 transcriptional effector. Proc Natl Acad Sci U S A. 2010; 107(30):13432-7.

83. Wang $Y$, Masuyama H, Nobumoto E, Zhang G, Hiramatsu Y. The inhibition of constitutive androstane receptor-mediated pathway enhances the effects of anticancer agents in ovarian cancer cells. Biochem Pharmacol. 2014;90:356.

84. Zhang WJ, Xu DF, Fan QX, Wu XA, Wang F, Wang R, et al. Arsenic trioxide restores ERalpha expression in ERalpha-negative human breast cancer cells and its treatment efficacy in combination with tamoxifen in xenografts in nude mice. Zhonghua Zhong Liu Za Zhi. 2012;34(9):645-51.
85. Zheng CY, Lam SK, Li YY, Fong BM, Mak JC, Ho JC. Combination of arsenic trioxide and chemotherapy in small cell lung cancer. Lung Cancer. 2013; 82(2):222-30.

86. Wen X, Li D, Zhang Y, Liu S, Ghali L, lles RK. Arsenic trioxide induces cervical cancer apoptosis, but specifically targets human papillomavirus-infected cell populations. Anti-Cancer Drugs. 2012;23(3):280-7.

87. Wu DD, Xiao YF, Geng Y, Hou J. Antitumor effect and mechanisms of arsenic trioxide on subcutaneously implanted human gastric cancer in nude mice. Cancer Genet Cytogenet. 2010;198(2):90-6.

\section{Submit your next manuscript to BioMed Central and we will help you at every step:}

- We accept pre-submission inquiries

- Our selector tool helps you to find the most relevant journal

- We provide round the clock customer support

- Convenient online submission

- Thorough peer review

- Inclusion in PubMed and all major indexing services

- Maximum visibility for your research

Submit your manuscript at www.biomedcentral.com/submit
Biomed Central 